\title{
1. Environmental enforcement networks: theory, practice and potential
}

\section{Grant Pink*}

\section{INTRODUCTION}

Individuals, such as Professor Dr Michael Faure of the Flemish High Council of Environmental Enforcement (VHRM), Ken Markowitz of the International Network for Environmental Compliance and Enforcement (INECE) and John Merritt of the Australasian Environmental Law Enforcement and Regulators neTwork (AELERT), have for many years now been stressing the importance of the role performed by environmental enforcement networks (hereafter EENs or networks).

These individuals and others ${ }^{1}$ frequently detail the issues and challenges

* Adjunct Research Fellow, School of Law, University of New England (UNE), Armidale, NSW, 2351, Australia (gpink2@une.edu.au); Director, Regulatory Capability and Performance Section, Australian Government's Department of the Environment, GPO Box 787, Canberra, ACT, 2600 (grant. pink@environment.gov.au); PhD Candidate, School of Behavioural, Cognitive and Social Sciences, UNE (gpink2@myune.edu.au). Any views or opinions expressed in this chapter are those of the author and not those of the University of New England, the Australian Government, or the Department of the Environment.

This chapter is adapted from a keynote address delivered on 13 November 2013 during the Environmental Enforcement Networks: Concepts, Implementation and Effectiveness conference in Brussels, Belgium. The author acknowledges and thanks Dr Matthew Marshall and Ms An Stas for their advice and assistance in recasting the address into a chapter.

1 O'Leary, G and Lynott, DJ, 'The Effective Use of an Environmental Enforcement Network in Ireland' in INECE, 9th International Conference on Environmental Compliance and Enforcement: 24 June 2011, Whistler, British Columbia, Canada: Proceedings, INECE: Washington, 2011; Nicholson, M, 'Networking in Europe: How Networking and Cooperation have Helped Respond to Environmental Compliance and Enforcement Challenges in Impel Member Countries' in INECE, 9th International Conference on Environmental Compliance and Enforcement: 24 June 2011, Whistler, British Columbia, Canada: Proceedings, 
that draw participants together in various environmental enforcement networks (EENs or networks) activities including meetings, workshops and conferences. An element of each of these activities contributes towards participants gaining a more complete understanding of how EENs operate and function. Through a greater understanding of EENs, participants are better placed to leverage additional or enhanced benefits from EENs.

Anecdotally speaking, for over a decade now, what has become evident is that various professionals are drawn to or are called to environmental regulation and enforcement, such that it appears it is often more of a vocation than just a job. The professionals who attend various fora associated with EENs include people who could work in any number of government agencies, or non-governmental organisations (NGOs) across a number of important issues, or be involved in capacity building across those issues. Instead they choose, often quite deliberately, to invest their efforts and make their contribution to environmental protection by taking roles associated with regulation and enforcement.

The various fora reinforce the critical role EENs play in providing and building capacity for environmental regulatory agencies around the world. References in this chapter to the critical role played by EENs include: when they operate individually, bilaterally or multilaterally, and when they function at the sub-national, national, regional and international level.

\subsection{Acknowledgments and Additional Context}

It is broadly accepted that mainstream environmental protection agencies have existed for more than 40 years $^{2}$ and that the first EENs have now been operating for more than 20 years. $^{3}$ Therefore, it is common for

INECE: Washington, 2011; Pink, G and Lehane, J, 'Environmental Enforcement Networks: Development of a Network Evaluation Matrix' in INECE, 9th International Conference on Environmental Compliance and Enforcement: 24 June 2011, Whistler, British Columbia, Canada: Proceedings, INECE: Washington, 2011; Stas, A, 'The Flemish High Council of Environmental Enforcement - A Coordinated Environmental Enforcement Policy' in INECE, 9th International Conference on Environmental Compliance and Enforcement: 24 June 2011, Whistler, British Columbia, Canada: Proceedings, INECE: Washington, 2011.

2 For example; the Swedish Environmental Protection Agency, United States Environment Protection Agency and the Victorian Environment Protection Agency were established in 1967, 1970 and 1971 respectively.

3 Most notably INECE (the International Network for Environmental Compliance and Enforcement) established in 1990 at the international level and IMPEL (the European Union Network for the Implementation and Enforcement of Environmental Law) established in 1992 at a regional level. 
participants at the various fora to include EEN founders: these are the elders of the field.

These elders between them comprise an immense body of knowledge and experience as they:

- Were foundational members and key players in the bilateral partnership between the Dutch and the US which led to the launch of the International Network for Environmental Compliance and Enforcement (INECE) over 20 years ago and they remain actively involved to this day;

- Have similarly launched, or injected fresh ideas and energy into subnational (provincial), national and regional EENs;

- Have had experiences as officeholders and advocates for EENs in and across numerous countries; and

- On a daily basis intersect and interact with EENs.

Therefore, one of the key messages associated with engagement at the various EENs fora is to enable and encourage participants to draw upon this body of experience and knowledge. Not to do so is not only an opportunity missed - but wasted. At the same time, in terms of skills, knowledge and experience, EENs need to embrace fresh thinking and different perspectives, such as those emerging from more recently established networks. ${ }^{4}$

Taking a forward-looking approach enables all participants, regardless of whether it is their twentieth year in networks or it happens to be their first, to make a valuable contribution by adding their fresh perspectives as well as by testing and challenging other participants in terms of the current practices of EENs.

\subsection{Phases of Network Involvement and Corresponding Benefits}

EENs and managers alike should remain aware of the fact that participants, much like EENs and organisations themselves, are at various stages of professional maturity and competence. Furthermore, these different stages are graduated in such a way that as participants' awareness increases, so too does their ability to access and realise benefits (at an individual and agency level).

4 Like the Jordan Network of Environmental Compliance and Enforcement (JNECE) launched in July 2013, the West African Network for Environmental Compliance and Enforcement (WANECE) launched in September 2013 and the East African Network for Environmental Compliance and Enforcement (EANECE) launched in May 2010. 
Generally, the stages of maturity divide into the following loose categories:

Phase 1 - 'exposed but sub-conscious': In this phase it is not uncommon for participants to be vaguely aware of EENs and start attending network events. Despite this, their understanding of EENs remains extremely limited and lessons learned are not being captured.

Phase 2 - 'increasingly aware but not involved': In this phase participants consciously attend network events but don't actively participate, they don't necessarily return lessons back to their home agency and their understanding of EENs is developing but remains basic.

Phase 3 - 'aware and involved': In this phase participants begin to actively engage and perform a liaison or conduit type role between the network and their home agency. Often lessons learned are informally returned to the home agency and greater alignment between the activities of the home agency and network are identified. Participants now possess a sound working knowledge of EENs.

Phase 4- 'acutely aware and deeply involved': In this phase participants assume a key role in the EEN (e.g. project leader, member of the secretariat or board) and often become involved in the activities of a sister or overlapping network. The participant's home agency recognises engagement with EENs as a core activity and often incorporates the EEN role into the job description of the individual concerned. This phase sees extensive (sometime seamless) alignment between the activities of the home agency and the EEN. The participant's knowledge of EENs is comprehensive, which is necessary as their role often involves an aspect of high level advocacy for and on behalf of the EEN.

Phase 5 - 'researching networks': This phase sees participants researching EENs, as a social construct, in an effort to make them more effective for the individuals, agencies and institutions who subscribe to them. Phase 4 and 5 can often occur concurrently.

\section{THE THEORY OF NETWORKS}

\subsection{Research}

In terms of the theory of networks there are three types of contributors: academic, practitioner and pracademic: 
- Academic research is produced in academic and research institutions such as universities and think-tanks;

- Practitioner research refers to that conducted by those involved in the operational and practically oriented project work of networks; and

- Pracademic research is an academic contribution informed by the researcher's professional experience.

\subsection{What Are Networks? What Is Networking?}

There are some assumptions and misconceptions that can be associated with networks and networking. The two terms are used frequently and in such a way that they can become intertwined or be used interchangeably.

The three most common hits returned when conducting standard research into networks relate to 'business networking', 'social networking' and 'computer networks' (e.g. information and communication technology (ICT) systems).

Business networking can attract a stigma. It is often associated with shaking hands, exchanging business cards and is seen as involving a level of self-promotion. Simply put, it is an interaction about businesses. Business people, or commercial entities, are trying to make connections with people in an attempt to offer them a product or service, and enter into a commercial relationship with them.

Social networking has become increasingly pervasive in society. It involves making connections with people who are family, friends, colleagues and associates and then, in turn, connecting with their family, friends, colleagues and associates.

Computer (or data) networks allow computers to exchange data. There are some interesting comparisons, for illustrative purposes, between computer networks and EENs. In terms of:

- Servers: these take the form of EEN boards;

- Network nodes: these reflect the roles performed by clusters and project teams within EENs;

- Network links: these are akin to country/agency focal points and members; and

- Network engineers: these are the EEN secretariat.

This overview on networks and networking, from a broader context, provides a sense of what it is participants do when they network as a network. Equally it provides an insight into what it is others think participants might be doing when they network within a network. 
It is clear that not all networking is the same and not all networking (even at the same event) will be considered the same by all participants. As such - to challenge the collective thinking - the question 'Are networks really networks?' can be asked.

\subsection{Networks, Communities of Practice or Hybrid: and Does it Really Matter?}

To start the consideration it is worth noting that within professions, across workplaces and even at a national level when people meet to consider problems and develop solutions one of the terms in use is 'Communities of Practice' (CoPs).

Jean Lave and Etienne Wenger's book Situated Learning: Legitimate Peripheral Participation (1991) involved an analysis of five case studies of traditional apprenticeship systems. In it they observed how in each case a whole community served as a living curriculum for the newcomer. They called these communities 'communities of practice'. ${ }^{5}$

Wenger, McDermott and Snyder's book Cultivating Communities of Practice: A Guide to Managing Knowledge (2002) explains why communities of practice are a 'key to managing knowledge' and 'provides practical advice on the art of cultivating communities and on creating an organizational context to support communities' ${ }^{6}{ }^{6}$ CoPs like EENs are not static - they need ongoing maintenance.

Wenger, McDermott and Snyder's work '... creatively responds to two important issues that face all organisations: how to cultivate human imagination, and how to organise knowledge that is capable of tackling messy problems in the world without boundaries'. ${ }^{7}$ To a large extent that is precisely what EENs are attempting to do.

Environmental offences and crimes neither recognise nor respect borders whether they are sub-national, national or regional. Environmental regulation and enforcement is becoming an increasingly globalised issue. As such, gaining a greater appreciation of the techniques and approaches used by CoPs, is something worth considering, given that 'CoPs are groups of people who share a concern, a set of problems, or a passion

\footnotetext{
5 Wenger has written comprehensively on Communities of Practice and related matters. For more information on these writings (articles and books) including summaries see http://wenger-trayner.com/etienne/books/

6 Ibid.

7 Wenger, E, McDermott, RA and Snyder, W, Cultivating Communities of Practice: A Guide to Managing Knowledge, Boston USA: Harvard Business School Publishing, 2002, back cover.
} 
about a topic, and who deepen their knowledge and expertise in this area by interacting on an ongoing basis'. ${ }^{8}$

\subsection{Communities of Practice}

Lave and Wenger ${ }^{9}$ suggest that CoPs require three components, and those components are domain, community and practice. Considering each in turn:

- Domain

'A CoP has an identity defined by a shared domain of interest (e.g. radiologists ... history teachers ... football fans, etc.); it's not just a network of people or club of friends. Membership implies a commitment to the domain.' 10

- Community

'A necessary component is that members of a specific domain interact and engage in shared activities, help each other, and share information with each other.' ${ }^{\prime 1}$

'They build relationships that enable them to learn from each other. In this way, merely sharing the same job does not necessitate a CoP. A static website ... is not a community of practice.' ${ }^{12}$

'There needs to be people who interact and learn together in order for a $\mathrm{CoP}$ to be formed. Note that members do not necessarily work together daily, however [but would sometimes meet informally and that] these kinds of interactions were essential to making them a CoP.' ${ }^{\prime 3}$

- Practice

'A CoP is not just people who have an interest in something (e.g. sports or agriculture practices). The third requirement for a $\mathrm{CoP}$ is that the members are practitioners. ${ }^{14}$

'... interaction needs to be developed over time. A conversation with ... an expert on a subject matter that interests you does not

8 Ibid., p. 4.

9 Lave, J and Wenger, E, Communities of Practice: Learning, Meaning, and Identity, Cambridge: Cambridge University Press, 1998.

10 See Learning-Theories, n.d., at http://www.learning-theories.com/ communities-of-practice-lave-and-wenger.html

11 Ibid.

12 Ibid.

13 Ibid.

14 Ibid. 
in itself make a CoP. Informal conversations held by people of the same profession ... help people share and develop a set of cases and stories that can become a shared repertoire for their practice, whether they realize it or not'. ${ }^{15}$

Together, these aspects precisely describe the essence of EENs.

\subsection{Types of Networks}

EENs actually share characteristics with the three types of networks that Slaughter identifies: information networks, enforcement networks and harmonisation networks. ${ }^{16}$

\section{- Information networks}

'The glue of any transgovernmental network is the exchange of information and ideas. Put a group of environmental regulators, central bankers, or utilities commissioners in a room and they will begin talking about different techniques of regulation, commiserating about common problems, and brainstorming new approaches'. ${ }^{17}$

\section{- Enforcement networks}

'[This] type of network focuses primarily on enhancing cooperation among national regulators to enforce existing national laws and rules. As the subjects they regulate - from criminals to corporations - move across borders, they must expand their regulatory reach by initiating contact with their foreign counterparts. ${ }^{18}$

'At a very concrete level, enforcement cooperation is exactly the sharing of information and the collaborative development of specific enforcement strategies in individual cases. The next step is cooperating in strategic priority setting and targeting ... ${ }^{\prime 19}$

It is worth noting that capacity building is common to most enforcement networks. This, however, is quite often not based on altruism - instead '[i]t results from a recognition that a global regulatory system based on transgovernmental networks is only as strong as its weakest link'. ${ }^{20}$

\footnotetext{
15 Ibid.

16 See Slaughter, A M, A New World Order, New Jersey: Princeton University Press, 2004, pp. 52-61 for a comprehensive overview of the three types of networks.

17 Ibid., p. 52.

18 Ibid., p. 55.

19 Ibid, pp. 56-57.

20 Ibid, p. 57.
} 


\section{- Harmonisation networks}

'. . regulators may work together to harmonise regulatory standards, such as product-safety standards, with the overt aim of achieving efficiency'. ${ }^{21}$

A tangible example of this, across the European Union, driven by the European Union Network for the Implementation and Enforcement of Environmental Law (IMPEL), is the Recommended Minimum Criteria for Environmental Inspections (RMCEI) which is an attempt to achieve operational standardisation in spite of legislation and political differences. ${ }^{22}$

As Slaughter states, overall the three types of network contain parallel processes and points of convergence:

'[These] three types of networks have overlapping functions - harmonisation and enforcement networks also exchange information and offer assistance; information networks can also make common policy for their members under certain circumstances'. ${ }^{23}$

While EENs have these component parts, it is the focus and priority afforded information, enforcement and harmonisation that varies. Focus and priority can also vary significantly within a particular EEN, between clusters $^{24}$ or even between projects within a cluster.

\subsection{Primary Actors in Networks}

EENs tend to be made up of: governmental regulators, international governmental organisations, non-governmental organisations, consultants and, increasingly, academic and research institutions. In limited contexts, EENs can involve industry peak bodies and the regulated community.

21 Ibid, p. 59.

22 For more detailed information on the RMCEI see IMPEL (http://impel. eu/), n.d.; Liebregts, T M and Kramers, R, 'Doing the Rights Things: A Stepby-step Guidance for Planning of Environmental Inspections' in INECE, 8th International Conference on Environmental Compliance and Enforcement: 5-11 April 2008, Cape Town, South Africa: Proceedings (London: Cameron May Ltd, 2008).

23 Slaughter, A M, A New World Order, Princeton, NJ: Princeton University Press, 2004, p. 52.

24 In some networks clusters are known by other names such as working groups or sub-committees. These various bodies often propose, develop, conduct, review and monitor projects undertaken under the auspice of the network. For more information on clusters see http://impel.eu/about/clusters/ (IMPEL) and https://aelert.net/cluster-working-groups/ (AELERT). 


\subsection{Three Levels of Networks}

Slaughter considers that there are three 'levels' of network activity, which are networks comprised of:

- Executive officials that develop within established international organisations;

- Officials that develop under agreements negotiated by heads of state; and

- National regulators that develop outside any formal framework. ${ }^{25}$

Slaughter suggests that the last group, the networks of national regulators, has attracted the most attention over the past decade. ${ }^{26}$ Adding that what characterises this level of network is that they '... arise spontaneously from a need to work together to address common problems; in some cases members interact sufficiently autonomously to require the institutionalization of their activities'. ${ }^{27}$

\subsection{What Constitutes an Environmental Enforcement Network?}

In terms of EENs, as perhaps particularly understood by participants at EEN fora, Andrew Farmer's (2007) work is both informative and accurate. In his book, Handbook of Environmental Protection and Enforcement: Principles and Practice, he sets aside a chapter on networking, ${ }^{28}$ thoroughly covering the issue.

Farmer describes the structure and function of six more formally established networks of varying ages. Specifically he details the development, growth, activities, management and general functioning of the following networks:

- INECE;

- IMPEL;

- Commission for Environmental Cooperation (CEC);

- Asian Environmental Compliance and Enforcement Network (AECEN);

25 Ibid., p. 45.

26 Ibid.

27 Ibid.

28 See Chapter 9 - 'Networking' in Farmer, A, Handbook of Environmental Protection and Enforcement: Principles and Practice, London: Earthscan, 2007, pp. 249-262. 
- Regulatory Environmental Programme Implementation Network (REPIN); and

- Maghreb Enforcement Network (MEN).

Farmer's work will be considered in greater detail in the next section, 'Networks in Practice', but at this juncture it is worth noting that while the mission statements of networks contain information about their respective focus and goals, the literature has established that there are a number of functions which appear common to EENs. These include:

- Building relationships and strengthening capacity across jurisdictions;

- Sharing of information and experiences;

- Raising awareness and improving environmental compliance and enforcement efforts; and

- Developing consistent and standardised practices and procedures to support implementation of environmental enforcement. ${ }^{29}$

Additional variety in the role and focus of EENs can be seen in the numerous works of INECE, which is reflected in the information that it has developed, collated and maintained over a 25 -year period. ${ }^{30}$

\section{NETWORKS IN PRACTICE}

\subsection{Overview of Research}

In 2010 the author conducted research into EENs. As 'action research' it was research that related to a real-world problem or issue and sought a real-world practical solution. ${ }^{31}$

29 As an example, refer to the purpose and mission statements of the following networks: AELERT http://www.aelert.net; INECE http://www.inece.org; and the Network for Ireland's Environmental Compliance and Enforcement (NIECE) http://www.epa.ie/enforcement/network/\#.UwAlzVVWFIo

30 The INECE website contains a vast amount of information across a myriad of issues relating to compliance and enforcement of environmental law. It also details the history, theory and practice of environmental enforcement networks themselves. Most notably from a research perspective it contains the proceedings from the nine conferences (1990, 1992, 1994, 1996, 1998, 2002, 2005, 2008 and 2011) held thus far.

31 For more on action research see O'Leary, Z, The Essential Guide to Doing Research, London: Sage, 2007, p. 139 and Robson, C, Real World Research, 2nd edn, Malden, MA: Blackwell Publishing, 2002. 


\subsubsection{Research questions}

In terms of the research, the study sought to answer two questions:

- Was there utility in environmental enforcement networks?; and

- If utility was established, how can environmental enforcement agencies maximise the benefit they derive from their involvement with environmental enforcement networks?

\subsubsection{Research participants}

Importantly, to give the research practical application, all of the research participants surveyed in the course of the study had:

- Direct environmental compliance and enforcement responsibilities within a national or provincial, environmental enforcement agency; and

- They also had formal roles within one or more of the networks studied.

The research participants were well placed to provide information relevant to the research questions as collectively they have contributed, participated in and gained experience from seven countries, eight agencies, 14 networks (covering those that are sub-national, national, regional and global) and have had associations with networks that have been established for between six and 25 years. It is also worth noting that they have had approximately from ten to forty years of experience in government service, and have had experience as an office holder in a network ranging from three to 22 years. ${ }^{32}$

\subsection{Research Data}

The research data, whether in questionnaire or interview format, focused on collecting information across four broad areas namely: Involvement, Value, Effectiveness and Support for networks.

\subsubsection{Questionnaire}

The questionnaire consisted of nine questions which were specifically designed to elicit information relating to:

32 See Pink, G, 'Environmental Enforcement Networks: A Qualitative Analysis', 2010, http://ssrn.com/abstract=1803179 (accessed on 14 April 2011), pp. 15-16. 
- The number of networks that a particular agency was actively associated with (Q1);

- An assessment of return for effort expended (Q2);

- The main benefits and challenges encountered through an agency's association with various networks (Q3 \& 4);

- How information from the network is made available to agency staff and their level of understanding of the network (Q5, 6 \& 8); and

- The level of support provided by an agency to networks (Q7 \& 9).

\subsubsection{Interview}

The interview consisted of six questions which were specifically designed to elicit more detailed and comprehensive information than that which was obtained from the questionnaire. The interview questions sought specific examples and descriptions of:

- The benefits of networks (Q1);

- The challenges of networks (Q2);

- The strategies employed by agencies to derive enhanced benefits from networks (Q1);

- The strategies employed by networks to provide greater benefits to members (Q4); and

- General advice that might be of use to those considering involvement in networks (Q5 \& 6).

\subsection{Analysis}

The questionnaire and interview data were initially subjected to iterative thematic analysis to determine the dominant and common themes. $^{33}$

The results were subjected to an analysis of strengths, weaknesses, opportunities, and threats (SWOT).$^{34}$ The outcomes of the SWOT analysis were then assessed and shaped into the policy options and recommendations for agencies considering involvement with networks.

33 Ibid., p. 18.

34 For more on SWOT analysis and its application see Heldon, CE, 'Exploratory Analysis Tools' in J Ratcliffe (ed.), Strategic Thinking in Criminal Intelligence, 2nd edn, Sydney: The Federation Press, 2009, 124-146 and Prunckun, H, Handbook of Scientific Methods of Inquiry for Intelligence Analysis, Lanham: Scarecrow, 2010, pp. 136-137. 


\subsection{Findings}

\subsubsection{Overview}

The objective of this research was to arrive at a set of policy options that could be considered by decision makers within agencies as part of assessing how their agency might obtain greater benefits from network association.

Table 1.1 shows the themes that emerged from an examination of each of the SWOT factors. The findings were consistent with those of Farmer, who notes that EENs differ in terms of formality, spanning the range of informal, semi-formal and formal. ${ }^{35}$ Equally, the research confirmed, through participant testimony, that ' ... [e]nforcement networks typically spring up due to the inability of government officials in one country to enforce that country's laws' ${ }^{36}$ The research also corroborated the comments of Achim Steiner, the Executive Director of the United Nations Environment Programme (UNEP) who believes that '... cooperation occurs only when diverse national interests converge, participating officers have been able to step outside narrow national boundaries, [and] understand each other's issues ....37

\subsubsection{The study}

The study established that there is utility in networks across the countries and networks studied. It also identified a range of strategies and activities that could be used by environmental enforcement agencies to assist them in maximising the benefits they derive from their network engagement.

The literature (academic, practitioner and pracademic alike) noted a proliferation of networks since the 1990s. It also reinforced the key role played by institutions such as INECE globally, as well as regional EENs (with IMPEL and AELERT providing an example from each hemisphere).

The study, as action research, focused particular attention on how agencies might best utilise networks to assist them in achieving improved environmental enforcement outcomes. Moreover it determined that EENs:

35 See Farmer, A, Handbook of Environmental Protection and Enforcement: Principles and Practice, London: Earthscan, 2007, pp. 249-262.

36 Slaughter, A-M, A New World Order, New Jersey: Princeton University Press, 2004, p. 19.

37 Steiner, A, Foreword in Networking Counts: Combating Illegal Trade in Ozone Depleting Substances, Paris: United Nations Environment Programme, 2007, p. 2. 
Table 1.1 SWOT analytical matrix-environmental enforcement networks

\begin{tabular}{lll}
\hline & \multicolumn{2}{l}{ Analysis of Strengths, Weaknesses, Opportunities and Threats } \\
\cline { 2 - 3 } & Supportive & Detrimental \\
\hline Internal & Strengths & Weaknesses \\
(to networks) & $\bullet$ Enhanced contacts & $\bullet$ Lack of active participation \\
& $\bullet$ Operational benefits & $\bullet$ Lack of resources \\
& $\bullet$ Accessing better practices & $\bullet$ Criticality of network \\
& & secretariats \\
External & Opportunities & - Project completion rates \\
(to networks) & $\bullet$ Representation & Threats \\
& $\bullet$ Reporting & - Inability to sustain internal \\
& $\bullet$ Benefits & capacity \\
& $\bullet$ Communication & $\bullet$ Loss of key staff \\
& $\bullet$ Events & distribution \\
& $\bullet$ Knowledge management & \\
\hline
\end{tabular}

- require a strong ongoing secretariat;

- require ongoing commitment and leadership (which frequently falls to an energised few);

- are reliant upon ad hoc resources from disparate sources (which tend to involve a disproportionate resource burden on some members);

- lack enforceable governance arrangements; and

- involve a transitory (and at times non-representative) membership drawn from a variety of government and non-government organisations (often with vastly competing interests). ${ }^{38}$

The research produced 12 suggestions or recommendations as to how agencies might derive additional or increased benefit from EENs. Because these recommendations relate to potential benefits, as they resulted from the practical research, they will be covered in section 4, 'Potential of Networks'.

\subsubsection{Maximising benefits of network engagement: four broad areas - involvement, value, effectiveness and support}

As stated previously, the recommendations relate to the four broad areas of involvement, value, effectiveness and support (IVES): ${ }^{39}$

38 Pink, G., 'Environmental Enforcement Networks: A Qualitative Analysis', 2010, http://ssrn.com/abstract=1803179 (accessed on 14 April 2011), p. 8 .

39 Ibid., p. 802. 
- Involvement - Why do agencies and people become involved in networks?

- Value - What is the value that agencies hope to get out of their network interaction - and to some extent how is this value perceived and how is the value measured?

- Effectiveness - How effectively do agencies consider the networks are operating and where they would like them to operate more effectively?

- Support - What is the support that networks require to be in a position to be able to support network members?

\section{POTENTIAL OF NETWORKS}

\subsection{Actual and Potential Benefits}

Anderson suggests that '[if] a network structure is viewed as providing opportunity, then a key research question involves better understanding the characteristics that affect actors' abilities to realize this opportunity'. ${ }^{40}$

Whereas Adler and Kwon consider it is important to differentiate between the potential opportunities that social networks provide and realised opportunities'. ${ }^{41}$

In highlighting that there are potential and realised benefits (or value) in networks, Farmer concluded his chapter on networks with a checklist for environmental enforcement agencies (EEAs). His checklist was for agencies that are already participating in networks. It suggests how EEAs can maximise their benefit from such association. It also provides a prompt for those EEAs who are contemplating participating in networks. The checklist, asked:

1. Has the environmental enforcement authority a designated person responsible for coordination with the network?

2. Is it responsible for part-funding of network activities and, if so, is this fully incorporated in relevant financial planning?

3. Are effective mechanisms in place to identify staff members who might most effectively participate in relevant network activities?

40 Anderson, M H, 'Social Networks and the Cognitive Motivation to Realize Network Opportunities: A Study of Managers' Information Gathering Behaviors', in Journal of Organizational Behavior, 2008, vol. 29, 51-78, p. 54.

41 Ibid., citing Adler and Kwon, 2002. 
4. Are effective mechanisms in place to disseminate the results of network activities to those in the environmental enforcement authority who would benefit? ?2 $^{4}$

\subsection{Maximising and Leveraging Benefits}

The purpose of the author's previous research was to arrive at a set of policy options that could be considered by decision makers within environmental regulatory agencies, as part of assessing how their agency might be able to obtain greater benefits from network association. The results of the study suggest there are strategies and activities that agencies can utilise in an effort to gain greater benefit from their association with networks.

\subsection{Strategies for Increasing Benefits - Considering a Value Cycle}

It is important that any strategy directed towards increasing benefits recognises that benefits, especially in terms of value, occur within a cycle and/or in phases.

Wenger, Trayner and de Laat suggest that there are five phases to a value cycle. These phases are:

- Immediate value: activities and interactions;

- Potential value: knowledge capital;

- Applied value: changes in practice;

- Realised value: performance improvement; and

- Reframing value: redefining success. ${ }^{43}$

\subsubsection{Immediate value: activities and interactions}

'This is the most basic cycle of value creation. It considers networking/community activities and interactions as having value in and of themselves'. ${ }^{44}$ This is a common occurrence in the meetings, workshops and conferences convened by EENs - participants come together to share, compare and improve - it is how EENs operate. Network members benefit

42 Farmer, A, Handbook of Environmental Protection and Enforcement: Principles and Practice, London: Earthscan, 2007, p. 262.

43 Wenger, E, Trayner, B and de Laat, M, 'Promoting and Assessing Value Creation in Communities and Networks: A Conceptual Framework', Ruud de Moor Centrum, Open Universiteit, Rapport 18, 2011, http://www.open.ou.nl/ rslmlt/Wenger_Trayner_DeLaat_Value_creation.pdf, pp.19-21.

44 Ibid., p. 19. 
from sharing perspectives and finding similarities and commonalities of experience. ${ }^{45}$

\subsubsection{Potential value: knowledge capital}

It is important to realise (especially for those participants new to networks and for sponsoring agencies or funders) that not all the value produced by a community of practice or a network is immediately realised. Instead, like any relationship, 'activities and interactions can produce "knowledge capital" whose value lies in its potential to be realized later' ${ }^{46}$ What is interesting about potential value is 'that this potential can be useful even if it is never realized' ${ }^{47}$ For instance, one can learn from others what to do in a certain set of circumstances based upon that other party's experience. So even if that occurrence never eventuates there is potential value in the sense that 'it is useful and reassuring to have that knowledge just in case'. ${ }^{48}$

\subsubsection{Applied value: changes in practice}

Following on, 'knowledge capital' is a potential value, which may or may not be put into use. Whereby:

Adapting and applying knowledge capital in different contexts can lead to changes or innovations in actions, practice, tools, approaches, or organizational systems. Looking at applied value means identifying the ways practice has changed in the process of leveraging knowledge capital. ${ }^{49}$

\subsubsection{Realised value: performance improvement}

Equally, 'new practices or tools are not enough, even when applied'. ${ }^{50}$

It is therefore [critically] important not to simply assume that improved performance is the case when people change their practice, but to reflect on what effects the application of knowledge capital is having on the achievement of what matters to stakeholders, including members who apply a new practice. ${ }^{51}$

45 Pink, G, 'Environmental Enforcement Networks: A Qualitative Analysis', 2010, http://ssrn.com/abstract $=1803179$ (accessed on 14 April 2011).

${ }_{46}$ Wenger, E, Trayner, B and de Laat, M, 'Promoting and Assessing Value Creation in Communities and Networks: A Conceptual Framework', Ruud de Moor Centrum, Open Universiteit, Rapport 18, 2011, http://www.open.ou.nl/ rslmlt/Wenger_Trayner_DeLaat_Value_creation.pdf, p. 19.

47 Ibid.

48 Ibid.

49 Ibid., pp. 20-21.

50 Ibid., p. 21.

51 Ibid. 


\subsubsection{Reframing value: redefining success}

This is the last cycle of value creation and it is achieved when social learning causes a reconsideration of the learning imperatives and the criteria by which success is defined'. ${ }^{52}$ 'This can include reframing strategies, goals, as well as values. It can also include proposing new metrics for performance that reflect the new definition of success.'.53

\section{CONCLUDING THOUGHTS AND REMARKS}

Around twenty years ago when networks were starting up, there may have been a speculative aspect to engagement with them and the corresponding value expected from them. It is suspected that the thinking at the time would have been something like: bringing like-minded people together, who share common or similar challenges and attempting to capture and leverage the learnings and benefits, surely can only help. Most likely the thinking was without further or more complex consideration or agenda than that mentioned.

However, as time has passed, budgets have become tighter and key performance indicators more pervasive and prominent. As a result, there has been, and continues to be, a greater focus on the 'value proposition' for an agency's association with and involvement in networks. ${ }^{54}$

In answer, networks provide individuals, teams and agencies with access to an array of environmental compliance and enforcement expertise. Access to expertise such as this is particularly valued by practitioners and network office holders alike. Both these groups hope networks continue, especially when resources are reducing and are subject to closer examination. ${ }^{55}$

Networks seem able to provide unique utility in the particular field of environmental compliance and enforcement. Networks have the ability to coalesce environmental compliance and enforcement expertise. This enables agencies to engage in bilateral or multilateral projects and initiatives. This multiplication factor enables agencies to be involved in and

52 Ibid.

53 Ibid.

54 See Chapter 7 'Environmental Enforcement Networks: Their "Value Proposition" During Times of Reducing Resources and Budgets' from Grant Pink in Part II Benefits of Networks.

55 Pink, G, 'Assessing the Utility of Environmental Enforcement Networks: Maximising Benefits to Members' in INECE, 9th International Conference on Environmental Compliance and Enforcement: 24 June 2011, Whistler, British Columbia, Canada: Proceedings, INECE: Washington, 2011, pp. 802-803. 
benefit from projects and initiatives, which had it not been for the network most likely would not have come to fruition. ${ }^{56}$

The need to engage with networks and the benefits of this engagement in accessing the multiplication factor mentioned above is widely supported. For example, Achim Steiner, Executive Director, UNEP, states:

At UNEP, we believe global problems need global partnerships ... [E]nforcement networking is one small example of the benefit of such cooperation. ${ }^{57}$

Professor Malcolm Sparrow of the Harvard Business School, states:

If practitioners bite off too much, chances are they will choke. Bite off too little, and nobody will much care. Obviously an agency can take bigger bites than an individual or a department; and a consortium of institutions can presumably take even bigger bites without being overwhelmed. ${ }^{58}$

Professor Campbell Gemmell and Tony Circelli, CEO and Deputy CEO respectively of the South Australian Environment Protection Authority, in drawing upon their experiences with a number of EENs in Europe and Australasia, highlight and reflect upon the parallels and intersections of the journeys that environmental regulators take - and how it is we must learn from one another. ${ }^{59}$

Ken Markowitz, Managing Director of the INECE Secretariat, refers to the importance of 'networks that do, not networks that are'. This sentiment is consistent with the viewpoint expressed by Farmer, who suggests that "networking for its own sake (a "talking shop") has little value'. ${ }^{60}$

Overall, this desire to maximise the value of environmental enforcement networks will lead to the achievement of progress and improvement in the

56 Pink, G, 'Environmental Enforcement Networks: A Qualitative Analysis', 2010, http://ssrn.com/abstract $=1803179$ (accessed on 14 April 2011), pp. 62-63.

57 Steiner, A, Foreword in Networking Counts: Combating Illegal Trade in Ozone Depleting Substances, Paris: United Nations Environment Programme, 2007, p. 2.

58 Sparrow, MK, The Character of Harms: Operational Challenges in Control, New York: Cambridge University Press, 2008, p. 84.

59 See Chapter 8 from 'Part II Benefits of Networks' in this volume, 'Environmental Regulation and Enforcement Networks Operating in Tandem: a Very Effective Vehicle for Driving Efficiencies and Facilitating Knowledge Exchange and Transfer'.

${ }^{60}$ Farmer, A, Handbook of Environmental Protection and Enforcement: Principles and Practice, London: Earthscan, 2007, p. 261. 
fields of environmental regulation and protection. It is also recognition of the fact that we are all in this together.

\section{BIBLIOGRAPHY}

Adler, PS and Kwon, SW, 'Social Capital: Prospects for a New Concept', Academy of Management Review (2002), vol. 27, 17-40.

Anderson, MH, 'Social Networks and the Cognitive Motivation to Realize Network Opportunities: a Study of Managers' Information Gathering Behaviors', Journal of Organizational Behavior (2008), vol. 29, 51-78.

Bricknell, S, 'Environmental Crime in Australia', AIC Reports: Research and Public Policy Series 109 (Canberra: Australian Institute of Criminology 2010).

Clifford, M and Edwards, T, Environmental Crime (2nd edn, Burlington MA: Jones \& Bartlett Learning 2012).

Elliott, L, 'Combating Transnational Environmental Crime: "Joined Up" Thinking About Transnational Networks', in K Kangaspunta and IH Marshall (eds), Eco-Crime and Justice: Essays on Environmental Crime (Turin: UNICRI 2009), 55-77.

European Union Implementation and Enforcement of Environmental Law (IMPEL) website 'Cluster i: Improving Implementation of EU Environmental Law (Permitting, Inspection, Enforcement and Smarter Regulation)', http:// impel.eu/cluster-i/ (n.d.) (accessed 21 February 2014).

Farmer, A, Handbook of Environmental Protection and Enforcement: Principles and Practice (London: Earthscan 2007).

Gemmell, JC (Campbell) and Circelli, T, 'Environmental Regulation and Enforcement Networks Operating in Tandem: a Very Effective Vehicle for Driving Efficiencies and Facilitating Knowledge Exchange and Transfer', Conference Paper. Environmental Enforcement Networks: Concepts, Implementation and Effectiveness (Brussels: Flemish High Council on Environmental Enforcement 2013).

Heldon, CE, 'Exploratory Analysis Tools' in J Ratcliffe (ed.), Strategic Thinking in Criminal Intelligence (2nd edn, Sydney: The Federation Press 2009), 124-146.

International Criminal Policing Organisation (INTERPOL), Environmental Crime Programme; Strategic Plan 2011-2013 (Lyon: INTERPOL 2011), http://www.interpol.int/content/download/12670/87152/version/3/file/ StrategicPlan2011-2013.pdf (accessed 15 October 2013).

International Network for Environmental Compliance and Enforcement (INECE), Principles of Environmental Compliance and Enforcement Handbook, April 2009 (INECE 2009).

International Network for Environmental Compliance and Enforcement (INECE), 'Manual for Creating and Sustaining Regional Environmental Compliance and Enforcement Networks' (2012), http://inece.org/resource/network_manual/ (accessed 5 June 2012).

Lave, J and Wenger, E, Situated Learning: Legitimate Peripheral Participation (Cambridge: Cambridge University Press 1991).

Lave, $\mathrm{J}$ and Wenger, E, Communities of Practice: Learning, Meaning, and Identity (Cambridge: Cambridge University Press 1998). 
Learning-Theories: http://www.learning-theories.com/communities-of-practicelave-and-wenger.html (n.d.) (accessed 21 February 2014).

Lehane, $\mathbf{J}$ and Pink, G, 'Evolution of a Regional Environmental Enforcement Network: The Australasian Environmental Law Enforcement and Regulators neTwork (AELERT)' in INECE, 9th International Conference on Environmental Compliance and Enforcement: 24 June 2011, Whistler, British Columbia, Canada: Proceedings (Washington: INECE 2011).

Liebregts, TM and Kramers, R, 'Doing the Rights Things: A Step-by-Step Guidance for Planning of Environmental Inspections' in INECE, 8th International Conference on Environmental Compliance and Enforcement: 5-11 April 2008, Cape Town, South Africa: Proceedings (London: Cameron May Ltd 2008).

Mays, N and Pope, C, 'Rigour and Qualitative Research', British Medical Journal (1995) vol. 311, 109-112.

Miles, MB and Huberman, AM, Qualitative Data Analysis: An Expanded Source Book (2nd edn, Thousand Oaks, CA: Sage Publications 1994).

Nicholson, M, 'Networking in Europe: How Networking and Cooperation have Helped Respond to Environmental Compliance and Enforcement Challenges in Impel Member Countries' in INECE, 9th International Conference on Environmental Compliance and Enforcement: 24 June 2011, Whistler, British Columbia, Canada: Proceedings (Washington: INECE 2011).

O'Leary, G and Lynott, DJ, 'The Effective Use of an Environmental Enforcement Network in Ireland' in International Network for Environmental Compliance and Enforcement in INECE, 9th International Conference on Environmental Compliance and Enforcement: 24 June 2011, Whistler, British Columbia, Canada: Proceedings (Washington: INECE 2011).

O'Leary, Z, The Essential Guide to Doing Research (London: Sage 2007).

Organisation for Economic Co-operation and Development (OECD), Funding Environmental Compliance Assurance: Lessons Learned from International Experience (Paris: OECD 2005).

Pink, G, 'Assessing the Utility of Environmental Enforcement Networks: Maximising Benefits to Members' in INECE, 9th International Conference on Environmental Compliance and Enforcement: 24 June 2011, Whistler, British Columbia, Canada: Proceedings (Washington: INECE 2011).

Pink, G, Environmental Enforcement Networks: A Qualitative Analysis (2010), http://ssrn.com/abstract $=1803179$ (accessed on 14 April 2011).

Pink, G, 'Environmental Enforcement Networks: Their “Value Proposition” During Times of Reducing Resources and Budgets', Conference Paper. Environmental Enforcement Networks: Concepts, Implementation and Effectiveness (Brussels: Flemish High Council on Environmental Enforcement 2013).

Pink, G and Lehane, J, 'Environmental Enforcement Networks: Development of a Network Evaluation Matrix' in INECE, 9th International Conference on Environmental Compliance and Enforcement: 24 June 2011, Whistler, British Columbia, Canada: Proceedings (Washington: INECE 2011).

Pink, G and Lehane, J, 'Evaluation and Assessing Environmental Enforcement Networks: Through Use of the Network Evaluation Matrix', Conference Paper. Environmental Enforcement Networks: Concepts, Implementation and Effectiveness (Brussels: Flemish High Council on Environmental Enforcement 2013). 
Prunckun, H, Handbook of Scientific Methods of Inquiry for Intelligence Analysis (Lanham: Scarecrow 2010).

Robson, C, Real World Research (2nd edn, Malden, MA: Blackwell Publishing 2002).

Slaughter, A-M, A New World Order (New Jersey: Princeton University Press 2004).

Spapens, T, 'Cross-border Police Cooperation in Tackling Environmental Crime' in INECE, 9th International Conference on Environmental Compliance and Enforcement: 24 June 2011, Whistler, British Columbia, Canada: Proceedings (Washington: INECE 2011).

Sparrow, MK, The Character of Harms: Operational Challenges in Control (New York: Cambridge University Press 2008).

Stas, A, 'The Flemish High Council of Environmental Enforcement - A Coordinated Environmental Enforcement Policy' in INECE, 9th International Conference on Environmental Compliance and Enforcement: 24 June 2011, Whistler, British Columbia, Canada: Proceedings (Washington: INECE 2011).

Steiner, A, Foreword in Networking Counts: Combating Illegal Trade in Ozone Depleting Substances (Paris: United Nations Environment Programme 2007), 2.

United Nations Office on Drugs and Crime (UNODC), The Globalization of Crime: A Transnational Organized Crime Threat Assessment (Vienna: UNODC 2010).

Wenger, E, website: http://wenger-trayner.com/etienne/books (n.d.) (accessed 21 February 2014).

Wenger, E, McDermott, RA, and Snyder, W, Cultivating Communities of Practice: A Guide to Managing Knowledge (Boston USA: Harvard Business School Publishing 2002).

Wenger, E, Trayner, B and de Laat, M, Promoting and Assessing Value Creation in Communities and Networks: A Conceptual Framework (Ruud de Moor Centrum, Open Universiteit, Rapport 18 2011), http://www.open.ou.nl/rslmlt/ Wenger_Trayner_DeLaat_Value_creation.pdf

White, R, Crimes Against Nature: Environmental Criminology and Ecological Justice (Devon: Willan Publishing 2008).

White, R, (ed.) Environmental Crime: A Reader (Devon: Willan Publishing 2009).

White, R, 'Environmental Law Enforcement: The Importance of Global Networks and Collaborative Practices', Australasian Policing: A Journal of Professional Practice and Research (2011) vol. 3, no 1, 16-22.

White, R, 'NGO Engagement in Environmental Law Enforcement: Critical Reflections', Australasian Policing: A Journal of Professional Practice and Research (2012) vol. 4, no 1, 7-11.

Wijbenga, B, Ruessink, H, De Wit, A, and Kapitein, P, 'Environmental Policing in the 21 st Century - Background, Organisation and Experience in the Netherlands' in INECE, 8th International Conference on Environmental Compliance and Enforcement: 5-11 April 2008, Cape Town, South Africa: Proceedings (London: Cameron May Ltd 2008).

World Customs Organization (WCO), The Green Customs Initiative - Customs Protecting the Environment (n.d.), http://www.greencustoms.org/background/ (accessed on 8 October 2013). 
Zaelke, D, Kaniaru, D, and Kružíková, E, (eds) Making Law Work: Environmental Compliance \& Sustainable Development, Volume 1 (London: Cameron May Ltd 2005a).

Zaelke, D, Kaniaru, D, and Kružíková, E, (eds) Making Law Work: Environmental Compliance \& Sustainable Development, Volume 2 (London: Cameron May Ltd 2005b). 